RESEARCH ARTICLE

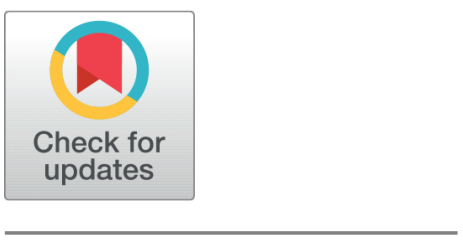

open ACCESS

Received: 22.03 .2021

Accepted: 15.04 .2021

Published: 19.06 .2021

Citation: Fareed SR, Memon M, Bhatti SM, Keerio MI (2021) Spatial Variability Portrayal of Soil Fertility Indicators in Apple Growing Area of Ziarat Balochistan Using Geostatistical Analysis. Indian Journal of Science and Technology 14(21): 1748-1757. https://doi.org/ 10.17485/IJST/v14i21.490

* Corresponding author.

nisamemon@gmail.com

Funding: None

Competing Interests: None

Copyright: ๑ 2021 Fareed et al. This is an open access article distributed under the terms of the Creative Commons Attribution License, which permits unrestricted use, distribution, and reproduction in any medium, provided the original author and source are credited.

Published By Indian Society for Education and Environment (iSee)

ISSN

Print: 0974-6846

Electronic: 0974-5645

\section{Spatial Variability Portrayal of Soil Fertility Indicators in Apple Growing Area of Ziarat Balochistan Using Geostatistical Analysis}

\author{
S R Fareed ${ }^{1}$, M Memon ${ }^{1}{ }^{*}$, S M Bhatti ${ }^{1}$, M I Keerio ${ }^{2}$ \\ 1 Department of Soil Science, Sindh Agriculture University, Tandojam, Sindh, Pakistan \\ 2 Khairpur College of Agricultural Engineering and Technology (KCAET)
}

\section{Abstract}

Objectives: To assess the soil heterogenicity and mapping of spatial distribution of soil fertility indicators for efficient nutrient management in apple orchards using geostatistical tool. Methods: Soil samples were collected from 50 apple orchards in district Ziarat where 20 from Ziarat and 30 from Sanjavi tehsil. GPS locations were marked at each orchard. Four soil cores were dug below each of the 8 apple tree canopy and composited into one sample. The samples were air-dried, ground, sieved through $2 \mathrm{~mm}$ sieve and analyzed for soil texture, organic matter, $\mathrm{pH}, \mathrm{EC}$, macro ( $\mathrm{N}, \mathrm{P}$ and $\mathrm{K})$ and micro $(\mathrm{Cu}, \mathrm{Fe}, \mathrm{Mn}$ and $\mathrm{Zn}$ ) nutrients. Descriptive statistics was carried out using Microsoft Excel. Geostatistical analysis was conducted by ArcGIS 8.1. Findings: Texturally, soil of the apple orchards were grouped into silt loam, sandy loam and loam where silt loam was dominant class as $82 \%$ samples were silt loam. Soil was nonsaline $\left(0.42 \mathrm{dSm}^{-1}\right)$ and have $\mathrm{pH}$ in alkaline ranges (7.71-8.45) with average value of 7.93. Kjeldhal's $\mathrm{N}, \mathrm{AB}$-DTPA extractable nutrients i.e. $\mathrm{P}, \mathrm{K}, \mathrm{Cu}, \mathrm{Fe}, \mathrm{Mn}$, and $\mathrm{Zn}$ were in the range of $0.02-0.15 \%, 0.26-9.41,21.0-203.60,0.21-1.35,0.25-$ $6.29,0.41-65.97$ and $1.80-27.01 \mathrm{mgkg}^{-1}$ respectively. Most of the orchards (54\%) expressed soil organic matter in adequate range and $46 \%$ orchards' soil showed medium level TN. Low level P, K and Fe was noted in 72, 50 and 74\% orchards' soil. The findings of geostatistical analysis showed that $\mathrm{Soil} \mathrm{pH}, \mathrm{Cu}$ and $\mathrm{Mn}$ had a weak spatial autocorrelation. While $T N$, and $Z n$ had a medium whereas $P, K$ and Fe had a higher spatial autocorrelation. Novelty: This research study provides procedural input for precise utilization of fertilizers as per soil properties of the area with minimum wastage and greater output.

Keywords: apple orchard; geostatistics; plant nutrients; soil properties; spatial variability

\section{Introduction}

Apple has prominent place in fruits crops globally and are grown on 4.72 million ha with production of 87.24 million tons ${ }^{(1)}$. In Pakistan, apples are generally grown in hilly areas and the major contribution come from Balochistan and Khyber Pakhtunkhwa provinces. During 2017-18, the area under apple cultivation was 88,589 hectares with 
annual production of 564,693 tons. About $91 \%$ of the area and $87.1 \%$ of the production was contributed by Balochistan. While, a small production of 12.3\%, (area 8.5\%) came from Khyber Pakhtunkhwa. The remaining traces of apple production came from Punjab ${ }^{(2)}$. In comparison to the neighboring and developed countries the average apple production $\left(6.75\right.$ tons $\left.^{-1}\right)$ in Pakistan is quite low that can be attributed to poor soil functions particularly due to calcareousness and alkaline nature coupled with low organic matter. These factors are responsible for affecting the availability of macro and micronutrients in the soil ${ }^{(3,4)}$, and have caused deficiencies of $\mathrm{N}, \mathrm{Fe}$ and $\mathrm{Zn}$ which are prevailing in the entire apple growing regions of Balochistan.

The overall soil physical, chemical and biological properties are imperative in maneuvering soil quality indicators that have close link with inconsistency in soil productivity ${ }^{(5)}$. For monitoring of soil functions and nutrient management, it is critical to comprehend the patterns of spatial variability ${ }^{(6)}$. The variation in soil parent material, soil surface features, type of vegetation, soil management practices and unevenness of field have caused spatial variability of soil properties ${ }^{(7-9)}$. Such variation has affected agriculture productivity economically and environmentally and have implicated the workability, plant essential nutrients management and sustainability of agricultural lands ${ }^{(10-12)}$. Several research studies have assessed the soil variability across different geographical locations and spatial scale including soil physical, chemical and biological properties ${ }^{(13-17)}$. But, most of the studies have been conducted on farmlands, grass and forestlands and very limited studies are available on the characterization of spatial variability of soil in apple orchards. In Australia, a group of researchers described the variability of soil organic matter and electrical conductivity in apple orchards using ordinary kriging ${ }^{(12)}$. While, another group of researchers in Romania characterized spatial variability pattern of soil physical properties in apple orchards and in UK Deakin et al. ${ }^{(18)}$ studied the microbial community structure on spatial scale. Guo et al. ${ }^{(19)}$ and Zhang et al. ${ }^{(20,21)}$ predicted SOM, EC, pH and macronutrients in apple orchards through country based spatial variability. Similarly, Sharma and Sood ${ }^{(22)}$ used geostatistical analysis and predicted spatial variability of soil $\mathrm{pH}, \mathrm{EC}, \mathrm{SOM}, \mathrm{N}, \mathrm{P}, \mathrm{K}, \mathrm{Ca}$ and $\mathrm{Mg}$ in apple orchards in Himalayan region and observed that $69.6 \%$ soil samples indicated $\mathrm{N}$ level in critical range, $\mathrm{P}$ and $\mathrm{K}$ were in high range.

Soil nutrient status in different apple orchards was evaluated by group of researchers ${ }^{(23-25)}$ and exhibited that in three districts included Pishin, Quetta and Ziarat soil N was low, AB-DTPA extractable P was found in the range of 2.8 to $9.5 \mathrm{mg} \mathrm{kg}^{-1}$ indicating low P in Quetta and Ziarat and medium in Pishin. Even though, higher AB-DTPA extractable K (277 and $214 \mathrm{mg} \mathrm{kg}-1)$ was observed in soil of Quetta and Pishin districts. While, Hidayatullah et al. ${ }^{(26)}$ documented soil Zn concentration in different apple orchards and found 15 orchards low in the available $\mathrm{Zn}$ concentration. The status was relatively better in other apple growing districts of Kalat, Killa Abdulla, Pishin and Quetta. Fruit orchard soils in alkaline calcareous environment generally exhibited micronutrients deficiencies particularly iron and zinc $^{(27)}$.

The application of fertilizer by traditional methods in places with varying nutrient status is now considered unsuitable and inefficient for the reason that from place to place soil fertility varies expressively. Unwise fertilizer application i.e. overapplication can of course be a wastage of fertilizer with hazardous environmental consequences. Geostatistical tools have been proved most effective in showing the distribution and pattern of spatial variation of soil nutrients and chemical properties ${ }^{(28)}$. In geostatistics, Kriging interpolation algorithm play an utmost beneficial and effective role in determination of the location and properties of variable functions of preliminary data that is used for evaluation of unknow values by impartial linear approximation ${ }^{(28)}$. Consequently, characterization of spatial variability of soil nutrient is the initial phase for nutrient management in precision agriculture. GIS mapping of soil nutrients based on spatial variability is prepared by geostatistical analysis that can make the application of fertilizer possible in balanced form ${ }^{(28)}$. The unknown data between samples require approximation as the sampling of soil is conducted irregularly and so such data estimation is termed interpolation because in neighborhood area where no sampling is done, unknown soil data is estimated with the help of sampled data ${ }^{(29)}$. Basically, Kriging interpolation predicts the soil nutrients value of unsampled area with the help of Semi variance map ${ }^{(30,31)}$. Keeping in view the importance of spatial variability soil properties in precise nutrient management as critical for better and sustainable crop productivity, this study was aimed to characterize spatial distribution and mapping of soil fertility indicators through geostatistical analysis as well as to provide procedural input for precise utilization of fertilizers according to specific soil characteristics of the area with least expenditure and better productivity.

\section{Materials and Methods}

\subsection{Site description}

District Ziarat is comprised of $1487 \mathrm{~km}^{2}$ area and one of the smallest districts of the province located at $30^{\circ} 22^{\prime} 51$ North and $67^{\circ} 43^{\prime} 37$ East at an altitude of 2453 meters (8050 feet). The world's largest Juniper Forest makes Ziarat famous for the second largest Juniper forest in the world. Administratively the district has two tehsils with seven union councils and situated in east of Quetta at a distance of $70 \mathrm{~km}(\mathrm{GoB}, 2012)$. It is mountain locked district distributed into several valleys with altitude of 1,800 to 3,488 meters. The prominent vallys are Kach, Kawas, Ziarat, Zandra, Mangi, Mana and Gogi Ahmadoon. The land 
area of district can be categorized as flood land, plain land and stony land. The flood water coming from high mountains areas along with mixed material deposited at the lower end forming flood lands. The natural terraces on the mountainous area later developed into plain lands. The stony lands have not been used for cultivation. Parent material of the area is shallow containing lime, along with coal, marble (dimensional stone), calcite and laterite (titanium). Laterite deposits contain only one to two percent titanium oxide along with high iron and aluminum contents which stretch over an area of 65 kilometer from Ziarat towards Sanjavi. Major area of the district land has been under apple orchard cultivation along with other fruits such as cherries, plums, apricots, almonds, grapes, etc.

\subsection{Soil sampling and processing}

Soil samples were collected with help of soil auger from 50 apple orchards of two tehsils (Ziarat and Sanjavi) and seven union councils (Kach, Kawas, Ziarat Sanjavi, Mana, Warchm and Poi) of district Ziarat. Under Ziarat tehsil, 5 orchards were selected each from Ziarat and Zandra,10 from Kawas, 9 from Mana and 5 from Warchum. Under Sanjavi tehsil, 13 orchards were collected from Sanjavi, and 3 from Poi union councils. A total of 1600 soil samples $(0-30 \mathrm{~cm})$ were collected from 50 apple growing orchards of district Ziarat in the month of August. GPS coordinates of each location in the apple orchards were recorded. To fulfill the criteria of representative sampling, 8 trees were randomly selected in each apple orchard. Four soil cores were dug below each of the 8 apple tree canopy and composited into one sample. Transparent polyethylene bags were used to preserve the soil samples. The soils samples were unpacked, air-dried and ground using wooden pestel mortar. Finally, the samples were sieved through $2 \mathrm{~mm}$ sieve. The sieved samples were transferred into air-tight plastic jars.

\subsection{Soil analysis}

Soil samples were analysed for texture, organic matter, $\mathrm{pH}, \mathrm{EC}$, macro and micro nutrients (N, P, K, Cu, Fe, Mn and $\mathrm{Zn}$ ) concentration. Soil texture of soil samples was carried out by Bouyoucos hydrometer method ${ }^{(32)}$. The percent sand, silt and clay were calculated from hydrometer readings and textural class was allocated by using the textural triangle ${ }^{(33)}$. The organic matter content of soil was determined by oxidizing method ${ }^{(34)}$. Electrical conductivity and $\mathrm{pH}$ were determined in $1: 2$ soil to deionized water ratio ${ }^{(35)}$ using $\mathrm{pH}$ meter (Model WTW pH 720) and EC meter (Model HI 8033). Available P and K by AB-DTPA extraction method ${ }^{(36)}$. These extracts were used to determine the quantity of $\mathrm{P}, \mathrm{K}, \mathrm{Cu}, \mathrm{Fe}, \mathrm{Mn}$ and $\mathrm{Zn}$. Phosphorus in the samples by spectrophotometry as detailed under Olsen et al. ${ }^{(37)}$ for blue colour development using spectrophotometer (Model ANA 75). While, $\mathrm{K}$ in the extracts was quantified by emission spectroscopy using Flame photometer (JENWAY PFP 7). Total nitrogen by Kjeldahl's method ${ }^{(38)}$. While, micronutrients as extracted by AB-DTPA methods were quantified on atomic absorption spectrophotometer (AA-6300 SHIMADZU with GFA-EX7i Graphite Furnace Atomizer).

\subsection{Descriptive statistic and spatial variability}

Descriptive statistics including minimum, maximum, mean, mode, standard deviation (SD), and coefficient of variation of chemical properties was carried out using Microsoft Excel.

\subsection{Spatial variation in soil nutrients}

The special variation of Kjeldhal's N, and AB-DTPA extractable nutrients i.e. $\mathrm{P}, \mathrm{K}, \mathrm{Cu}, \mathrm{Fe}, \mathrm{Mn}$ and $\mathrm{Zn}$ in the apple orchard soils was assessed by the kriging interpolation method. The Ordinary Kriging Model ${ }^{(39)}$ as given by has proved to be the most familiar type of Kriging and provides an accurate estimate for an area around a measured sample. Spatial dependence between two locations was calculated as a function of distance through semivariogram, which used the following equation as given here.

$$
\hat{\gamma}(h)=\frac{1}{N(h)} \sum_{i=1}^{N(h)}\left[z\left(x_{i}\right)-z\left(x_{i}+h\right)\right]^{2}
$$

Here, $\gamma(\mathrm{h})$ described the magnitude of the lag distance between the two sample locations. While $\mathrm{N}(\mathrm{h})$ described the number of observation pairs, separated by $\mathrm{h}$ (the distance), $\mathrm{Z}$ (the random variable) and $\mathrm{x}$ is the random variable at specific location.

Three parameters nugget variance $(\mathrm{Co})$, sill $(\mathrm{Co}+\mathrm{C})$ and range $(\mathrm{a})$ were used to illustrate the structure of model in semivariogram analysis. Among different functions i.e. stable, circular, spherical, exponential and Gaussian, the semivariogram uses the suitable model. After applying the function, best fitted mathematical models of semivariogram were selected for assessing the integrity of the model to the data. The prediction errors such as mean, root mean standard square error (RMSSE), average standard error (ASE) and root mean square error (RMSE) were calculated and analyzed by using the Geo-Statistical 
software (GS+). Predictive maps of soil nutrients (i.e. N, P, K, Cu, Fe, Mn and Zn) were generated using a semivariogram model through ordinary kriging, which was used further to transform the sampling location data into incessant fields. This was carried out by ArcGIS 8.1.

\section{Results}

Soil properties are influenced by a variety of factors including soil parent material, topography, climatic conditions, soil biota, and other soil physical and chemical processing factors. The soil of apple orchards across district Ziarat was studied for soil fertility indicators included soil texture, organic matter, $\mathrm{pH}, \mathrm{EC}$, Total N, AB-DTPA extractable macro ( $\mathrm{N}, \mathrm{P}$ and $\mathrm{K}$ ) and micro $(\mathrm{Cu}, \mathrm{Fe}, \mathrm{Mn}$ and $\mathrm{Zn})$ nutrients. The spatial variability and spatial dependence of these variables were investigated using geostatistical analysis except soil texture and organic matter.

\subsection{Soil texture}

The proportion of soil fractions into sand, silt and clay (Table 1) of apple orchard soils showed that silt was the dominant fraction. The data showed that sand values ranged between $8.30-73.70 \%$, silt $9.20-79.60 \%$ and clay $7.10-26.70 \%$ with average values of $27.97 \%, 57.66 \%$ and $14.39 \%$. Mode values depicted that silt percentage of majority of the samples was close to upper limit of the range, followed by sand and clay. The coefficient of variability manifested wide dispersion in sand content of the orchards and narrow one in silt and clay content. The textural class of 50 orchards soils represented three types of soil texture. The break down by the number of soil samples falling under different textural classes as shown in Figure 1 revealed $82 \%$ samples were silt loam, $16 \%$ were sandy loam and only $02 \%$ were loam (Figure 1). A group of researchers in Greece studied the spatial variability of soil texture along with other soil properties in apple orchards and noted moderate spatial autocorrelation for clay and silt and weak spatial autocorrelation for sand ${ }^{(40)}$. According to Saleem et al. ${ }^{(41)}$ that most soil of apple orchards were silty loam and clay loam in district Killa Saifullah.

Table 1. Soil properties in apple orchards

\begin{tabular}{|c|c|c|c|c|c|c|}
\hline Soil parameters & Minimum & Maximum & Mean & Mode & SD & $\mathrm{CV} \%$ \\
\hline Sand $(\%)$ & 8.30 & 73.70 & 27.97 & 18.70 & 18.70 & 66.86 \\
\hline Silt (\%) & 9.20 & 79.60 & 57.66 & 72.10 & 17.58 & 30.49 \\
\hline Clay (\%) & 7.10 & 26.70 & 14.39 & 14.60 & 4.65 & 32.29 \\
\hline Organic Matter (\%) & 0.31 & 2.91 & 1.39 & - & 0.16 & 11.81 \\
\hline Electrical conductivity (dS m-1) & 0.23 & 0.65 & 0.40 & 0.36 & 0.23 & 58.40 \\
\hline $\mathrm{pH}$ & 7.71 & 8.45 & 8.05 & 7.93 & 0.16 & 2.04 \\
\hline Kjeldahl's N (\%) & 0.02 & 0.15 & 0.07 & - & 0.03 & 41.54 \\
\hline Phosphorus (mg kg-1) & 0.26 & 9.41 & 3.10 & 2.02 & 2.07 & 66.54 \\
\hline Potassium (mg kg-1) & 21.0 & 203.6 & 67.0 & 57.75 & 31.69 & 47.27 \\
\hline Copper (mg kg-1) & 0.21 & 1.35 & 0.68 & 0.53 & 0.27 & 39.61 \\
\hline Iron (mg kg-1) & 0.25 & 6.29 & 1.54 & - & 1.24 & 80.10 \\
\hline Manganese (mg kg-1) & 0.41 & 65.97 & 8.86 & - & 11.80 & 133.12 \\
\hline Zinc (mg kg-1) & 1.80 & 27.01 & 5.11 & 4.83 & 3.71 & 72.63 \\
\hline
\end{tabular}

SD, Standard deviation; $\mathrm{CV}$, Coefficient of variablity

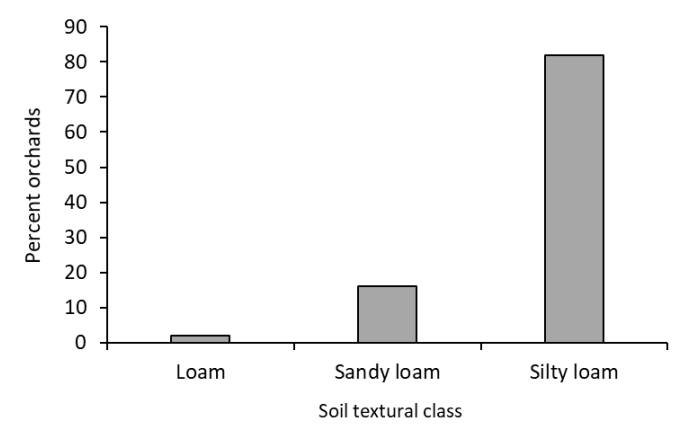

Fig 1. Textural class of apple orchard soils in Ziarat 


\subsection{Soil organic matter contents (\%)}

Total organic matter content was typical of our soils and was as low as $0.31 \%$ and as high as $2.91 \%$ with an average value of $1.39 \%$. Mode values showed that majority of the values were close to average values (Table 1). However, the coefficient of variability values refers to some spread of the data. The organic matter content revealed that 27 apple orchard soils were in the category of greater than $1.29 \%$ expressed as adequate. While, $15(30 \%)$ were between $0.86-1.29 \%$, expressed as medium. The remaining 8 orchard soils $(16 \%)$ were in the category below $0.86 \%$, expressed as low in organic matter content. Similar results were reported by Hussain et al. ${ }^{(42)}$ that in comparison to agriculture field, the orchards' soil indicated higher level of soil organic matter. Recently, another group of researchers studied the spatial and temporal dynamics of soil organic matter under various land use and topography in a watershed on Loess plateau China and found close relationship in spatial and temporal distribution of soil organic matter with soil parameters as a function of topography, land use and vegetation ${ }^{(20)}$. The high contents of soil organic matter are due to the application of manure in apple orchards by the farmers intentionally and is a general practice in all apple enterprises in the area. Sharma and Sood ${ }^{(22)}$ also recorded soil organic matter in the range of $0.5-1.0 \%$ in apple orchards during characterization of spatial variability of soil fertility in Himalayan region. Organic matter works as a source of nutrient supply as reported by many researchers that soil organic matter has close association with availability of nutrients ${ }^{(43-45)}$.

(a)

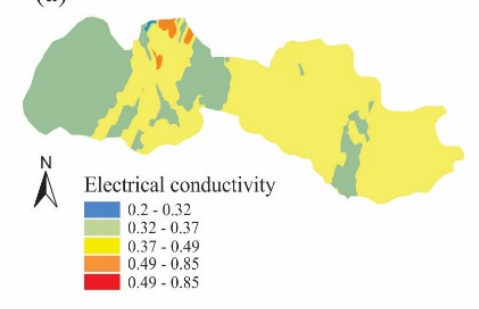

(d)

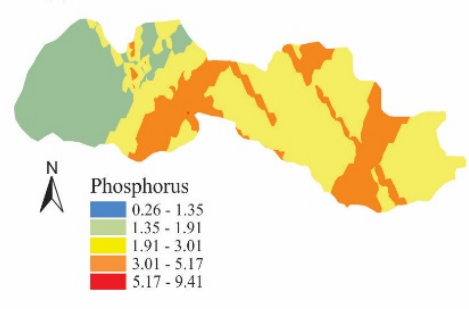

(g)

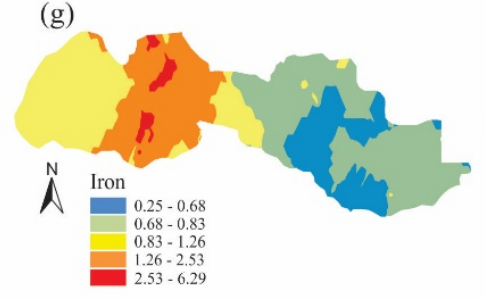

(b)

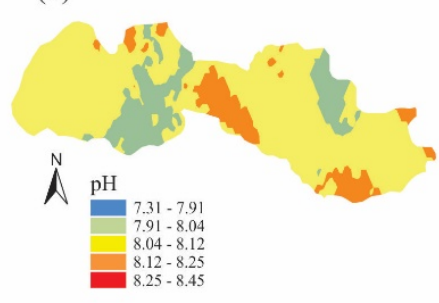

(e)

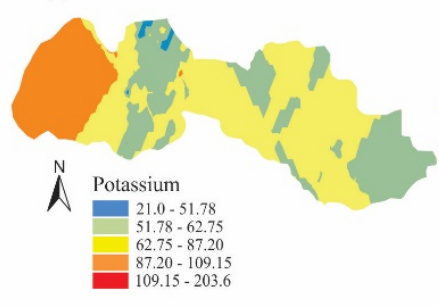

(h)

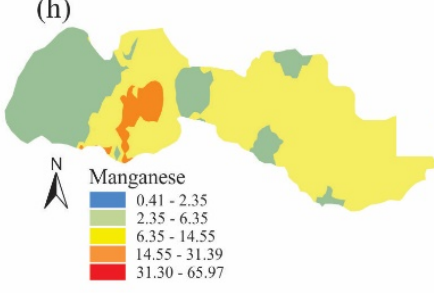

(c)

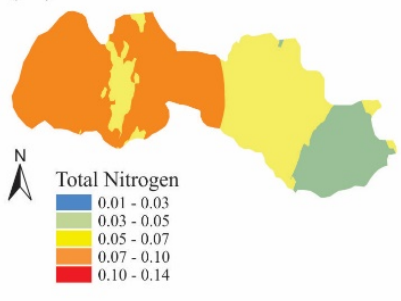

(f)

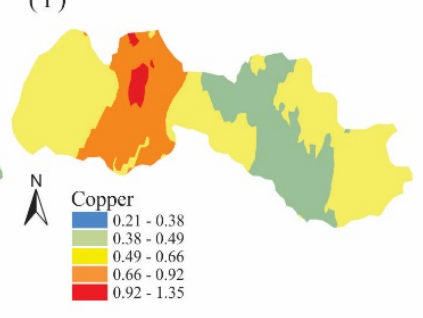

(i)

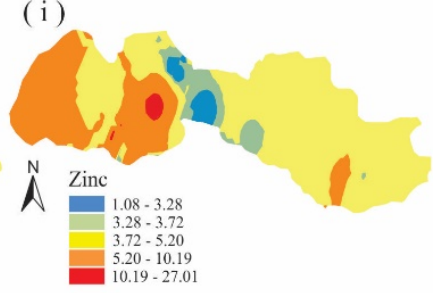

Fig 2. Spatial distribution maps (km) of a) Electrical conductivity $\left(\mathrm{dSm}^{-1}\right)$; b) $\mathrm{pH}$; c) Total Nitrogen (\%); d) Phosphorus (mg kg $\left.{ }^{-1}\right)$; e) Potassium $\left(\mathrm{mg} \mathrm{kg}^{-1}\right)$; f) Copper $\left(\mathrm{mg} \mathrm{kg}^{-1}\right)$; g) Iron $\left(\mathrm{mg} \mathrm{kg}^{-1}\right)$; h) Manganese $\left(\mathrm{mg} \mathrm{kg}^{-1}\right)$; and i) Zinc $\left(\mathrm{mg} \mathrm{kg}^{-1}\right)$ in soil of apple orchards, District Ziarat Balochistan

\subsection{Soil electrical conductivity and pH}

The data (Table 1) related to electrical conductivity values ranged between 0.20 and $1.85 \mathrm{dS} \mathrm{m}^{-1}$ with an average value of 0.40 $\mathrm{dS} \mathrm{m}{ }^{-1}$. Mode values of 0.36 showed that majority of the values were close to average values. The coefficient of variation showed narrow spread of the data. Table 2 showed that all orchard soils were non-saline. However, it was just one orchard which had electrical conductivity value of $1.85 \mathrm{dSm}^{-1}$. Similar results were reported by Hussain et al. ${ }^{(42)}$ who recorded electrical 
conductivity between 1.15 and $1.60 \mathrm{dSm}^{-1}$ in $77.42 \%$ orchards area in Karakoram Range while Zia-ul-Haque et al. ${ }^{\text {(46) }}$ studied the soil properties of apple orchard in Killa Saifullah Balochistan and noted EC below $4 \mathrm{dSm}^{-1}$ that demonstrates that there is no salinity in the apple growing area.

Table 2. Status of soil based on critical limits for apple

\begin{tabular}{|c|c|c|c|c|c|c|}
\hline \multirow{2}{*}{ Soil nutrients } & \multicolumn{3}{|c|}{ Critical limits } & \multicolumn{3}{|c|}{ Percent sample } \\
\hline & Low & Medium & Adequate & Low & Medium & Adequate \\
\hline Organic matter (\%) & $<0.86$ & $0.86-1.29$ & $>1.29$ & 16 & 30 & 54 \\
\hline Kjeldahl's N (\%) & $<0.05$ & $0.05-1.0$ & $>1.0$ & 38 & 46 & 16 \\
\hline Phosphorus (mg kg-1) & $<4.0$ & $4.0-7.0$ & $>7.0$ & 72 & 24 & 4 \\
\hline Potassium (mg kg-1) & $<60$ & $60-120$ & $>120$ & 50 & 44 & 6 \\
\hline Copper (mg kg-1) & $<0.2$ & $0.2-0.5$ & $>0.5$ & - & 26 & 74 \\
\hline Iron (mg kg-1) & $<2.0$ & $2.1-4.0$ & $>4.0$ & 74 & 20 & 6 \\
\hline Manganese (mg kg-1) & $<1.8$ & - & $>1.8$ & 10 & - & 90 \\
\hline Zinc (mg kg-1) & $<1.0$ & $1.0-1.5$ & $>1.5$ & - & - & 100 \\
\hline
\end{tabular}

Soil $\mathrm{pH}$ is the main driving force in biogeochemical processes that occurs in soil system and is considered as master variable in soil fertility indicators responsible for affecting the soil properties, nutrient availability and crop productivity. In this study, it was observed that the $\mathrm{pH}$ values varied within a narrow range of 7.71 and 8.45 with an average value of 8.05 . The mode value of 7.93 depicted that majority of the values were close to average values and this was very clear from the coefficient of variability (Table 1). The $\mathrm{pH}$ values given in Table 2 illustrated that $92 \%$ soils were classified as moderately alkaline (7.9-8.4), 6\% as slightly alkaline (7.4-7.8) and $2 \%$ as strongly alkaline as per USDA classification. The alkaline nature of soil is due to the presence of free carbonates particularly calcium carbonates and cannot change easily after addition of amendments because of its high buffering capacity. Khalid et al. ${ }^{(47)}$ reported that the calcareous nature of parent material and arid climatic conditions are the reasons of highly alkalinity. According to Hussain et al. ${ }^{(42)}$ that $62.9 \%$ orchard soil revealed pH in range of 7.63-7.81while in orchards $62.9 \%$ area fall in ranges of 7.63-7.81.

\subsection{Soil nutrients}

For better plant growth and soil health, the existence and availability of plant essential nutrients is prerequisite ${ }^{(48)}$. However, in calcareous and alkaline soil, the availability of nutrients is poor leading to low crop production that can be seen in the prevailing nutrient imbalances in apple orchards. Soil nutrient status assessed in various apple orchards across district Ziarat, is presented in Tables 1 and 2. The total nitrogen (TN) concentration in apple orchards' soil was as low as $0.02 \%$ and as high as $0.15 \%$ with an average concentration of $0.07 \%$. It was noted that $\mathrm{TN}$ was in medium range in $46 \%$ apple orchards and adequate in $16 \%$ orchards that might be due to increased level of soil organic matter. these results are in line with result of Zia Ul Haq et al. ${ }^{(46)}$ who revealed that TN in the surface soil was adequate in $77 \%$ apple orchards district Killa Saifullah. Similar results were reported by Hou et al. ${ }^{(49)}$ that in apple orchards' soil the increase in TN and AN (available nitrogen) was the result of N fertilizer application with high rate as well as organic $\mathrm{N}$ fertilizer for a long time. While, $38 \%$ orchard revealed low TN with critical limit of $<0.05 \%$. The reason of low $\mathrm{N}$ might be due low level of soil organic matter where farmers do not apply manure or compost. But phosphorus and potassium were observed in low ranges in 72 and $50 \%$ orchards. The reasons might be due unavailability of $\mathrm{P}$ in calcareous soil and secondly no use of phosphatic fertilizer. Comparison of observed available $\mathrm{P}$ values with critical limits on percentage basis (Table 2) showed that only $4 \%$ samples were above $7.0 \mathrm{mg} \mathrm{kg}^{-1}$. While, $72 \%$ orchard soils were below the critical limit of $4 \mathrm{mg} \mathrm{kg}^{-1}$ soil. This way, 96\% apple orchards had inadequate P. The AB-DTPA extractable $\mathrm{K}$ in the study area was in the range of 21.03 and $203.6 \mathrm{mgkg}^{-1}$ with average value of $67.0 \mathrm{mgkg}^{-1}$ (Table 1). On comparison with critical limits of available $\mathrm{K}$ extracted by AB-DTPA, only $6 \%$ orchard soils (6\%) showed $\mathrm{K}$ in adequate range but all the rest of orchards' soils were either low (50\%) or marginal (44\%). This headed to insufficient $\mathrm{K}$ in $94 \%$ apple orchards (Table 2). The low $\mathrm{K}$ in soil orchards might be due to parent materials and the other reason is high soaring cost of potassic fertilizer that farmers cannot afford to apply. A group of researchers studied the influence of land use on soil quality indicators in Karakoram region, Pakistan and found that in agriculture soil there was no difference in $\mathrm{K}$ concentration ${ }^{(50)}$. Contradicting results about AB-DTPA extractable K in apple orchards soil was noted by Zia Ul Haque et al. ${ }^{(46)}$ that only $3 \%$ orchards expressed low soil K level in Killa Saifullah district and varied with respect to soil depth and across different orchards.

In case of micronutrients, all the orchards' soils showed copper, manganese and Zin in adequacy ranges except iron which was low in $74 \%$ orchards (Table 2). Soil test values (Table 1) indicated that $\mathrm{Cu}$ concentration was between 0.21 and $1.35 \mathrm{mg}$ 
$\mathrm{kg}^{-1}$ with an average value of $0.68 \mathrm{mg} \mathrm{kg}^{-1}$ with wide variation as shown by coefficient of variability value of $36.91 \mathrm{mg} \mathrm{kg}^{-1}$. There was wide variation in Fe concentration. The lowest values were $0.25 \mathrm{mg} \mathrm{kg}^{-1}$ and highest as $6.29 \mathrm{mg} \mathrm{kg}^{-1}$. Thus, as a whole, $94 \%$ apple orchard soils were suffering from Fe nutrition. While, Mn concentration varied greatly from 0.41 to $65.97 \mathrm{mg} \mathrm{kg}^{-1} \mathrm{soil}$. Even then, the Mn concentration of only $10 \%$ apple orchards was low $\left(<1.8 \mathrm{mg} \mathrm{kg}^{-1}\right)$. In case of $\mathrm{Zn}$, all the apple orchards of Ziarat were adequate, having concentration greater than $1.5 \mathrm{mg} \mathrm{kg}^{-1}$ (Table 1). The values ranged between $1.80 \mathrm{mg} \mathrm{kg}^{-1}$ and 27.01 $\mathrm{mg} \mathrm{kg}^{-1}$ with average values of $5.11 \mathrm{mg} \mathrm{kg}^{-1}$. There was no deficiency of $\mathrm{Zn}$ in apple orchard soils. It is worth mentioning that apple trees require iron more than other fruit crops and the chelated iron is almost used by the farmers which is now-a-days have become quite expensive and applied quantity is very low that cannot meet the tree requirement. While, $\mathrm{Zn}$ is applied regularly as zinc sulfate annually or after every two years. The adequacy of $\mathrm{Cu}$ and $\mathrm{Mn}$ in soil is might be due to intrinsic capability of parent material. According to Ahmed et al. ${ }^{(51)}$ that increase in silt fraction enhance availability of nutrients. Primary mineral are the dominant minerals in the original parent material of sand and silt fraction ${ }^{(52)}$ that could be one of the reasons of moderate to adequate level of $\mathrm{Cu}, \mathrm{Mn}$ and $\mathrm{Zn}$ in the study area.

\subsection{Spatial variability of soil properties}

Geostatistical analysis is one of the important statistical tools which is principally used for assessment and mapping of soil characteristics at location of unsampled area. Spatial variability and dependence of soil parameters were determined by semivariogram and ordinary kriging. Variation caused by experimental error or smaller sampling scale is expressed by nugget. When the value of nugget is bigger than the minor measure process cannot be overlooked. The ratio of nugget and sill reveal variation in percentage instigated by stochastic factors to the total variation of the system. Actually, the ratio of nugget and sill shows autocorrelation among various parameters. Strong spatial autocorrelation of a variable is characterized by lower nugget and sill ratio $(<25 \%)$, moderate spatial autocorrelation is exposed by medium nugget and sill ratio (25-75\%) and weak spatial autocorrelation is signified by higher nugget-sill ratio $(>75 \%)$ respectively ${ }^{(52)}$. Spatial variability of soil electrical conductivity and $\mathrm{pH}$ was described by stable model dependent on the function of distance which were expressed as 0.11 and $0.00 \mathrm{~km}$ (Table 3 ). Nugget to sill ration is usually used for characterization of spatial dependence of variables ${ }^{(53)}$. The nugget to sill ratio for EC was $50 \%$ representing moderate spatial autocorrelation while for $\mathrm{pH}$ was $85.71 \%$ demonstrating weak spatial autocorrelation. Hou et al. ${ }^{(4)}$ observed the spatial variability of soil properties of apple orchards and reported that nugget to sill ratio of all the variables expressed strong spatial autocorrelation $(<25 \%)$ but the $\mathrm{pH}$ indicated moderate spatial autocorrelation of $47.8 \%$. The related closeness of average standardized error (ASE) and root mean square of standardized error (RMSE) confirmed that the prediction is correct (Table 3). The spatial distribution map of EC and $\mathrm{pH}$ as generated by semivariogram is depicted in Figure $2 \mathrm{a} \& \mathrm{~b}$ and the EC range of $0.37-0.49 \mathrm{dSm}^{-1}$ has covered the area of tehsil Sanjavi i.e Eastern part of the district Ziarat and some central area of tehsil Ziarat while the EC range of $032-0.37 \mathrm{dSm}^{-1}$ is expressed in Western pole along with some patches in the center of the district (Figure 2a). In case of spatial distribution of $\mathrm{pH}$, it was observed that $\mathrm{pH}$ range of 8.04 to 8.12 represent the whole soil of the district with minor patches showing $\mathrm{pH}$ range of 7.91-8.04 while the range of 7.31-7.91 covered negligible area (Figure 2b). Similar results were reported by Yang et al. ${ }^{(20)}$ that spatial variability of soil EC and pH in the field varied and noted strong dependence for EC (0.31) with spatial autocorrelation of $283.40 \mathrm{~m}$ and medium spatial dependence (0.50) for $\mathrm{pH}$ with spatial autocorrelation of $57.79 \mathrm{~m}$.

Table 3. Spatial dependence model of soil chemical properties

\begin{tabular}{|c|c|c|c|c|c|c|}
\hline Characteristics & $\begin{array}{l}\text { Applied } \\
\text { Model }\end{array}$ & Range A0 & Nugget:Sill & $\begin{array}{l}\text { Root Mean Square } \\
\text { Standardized Error }\end{array}$ & $\begin{array}{l}\text { Average Standardized } \\
\text { Error }\end{array}$ & $\begin{array}{l}\text { Root Mean } \\
\text { Square Error }\end{array}$ \\
\hline $\mathrm{EC}$ & Stable & 0.11 & 50.00 & 0.88 & 0.28 & 0.25 \\
\hline $\mathrm{pH}$ & Stable & 0.00 & 85.71 & 1.01 & 0.17 & 0.18 \\
\hline Nitrogen & Stable & 0.61 & 75.0 & 1.04 & 0.02 & 0.02 \\
\hline Phosphorus & Stable & 0.01 & 10.64 & 0.99 & 1.95 & 1.90 \\
\hline Potassium & Stable & 0.00 & 3.76 & 1.01 & 35.05 & 34.74 \\
\hline Copper & Stable & 0.08 & 85.36 & 0.95 & 0.22 & 0.20 \\
\hline Iron & Stable & 0.09 & 8.84 & 0.85 & 1.26 & 1.05 \\
\hline Manganese & Stable & 0.16 & 61.17 & 1.05 & 13.25 & 13.27 \\
\hline Zinc & Stable & 0.12 & 42.41 & 1.24 & 3.54 & 4.31 \\
\hline
\end{tabular}

The semivariogram of soil macronutrients (N, P and K) using stable model expressed distance of spatial dependence of 0.61 , 0.01 and $0.00 \mathrm{~km}$ for $\mathrm{N}, \mathrm{P}$ and $\mathrm{K}$ (Table 3). The nugget:sill ratio of 75 for $\mathrm{N}$ indicating weak spatial autocorrelation, 10.64 and 
3.76 for $\mathrm{P}$ and $\mathrm{K}$ exhibiting strong spatial autocorrelation. These results are in line with Hou et al. ${ }^{(49)}$ who reported 0.10 to 4.30 $\mathrm{km}$ ranges of spatial autocorrelation for $\mathrm{N}, \mathrm{P}, \mathrm{K}$ and $\mathrm{Zn}$. The prediction of these nutrients from unsampled area is correct because ASE and RMSE have related closeness. Similar results were also reported by many researchers ${ }^{(20)}$. While the map generated from semivariogram showing the spatial distribution of these nutrients is depicted in Figure $2 \mathrm{c}$-e. The medium level soil total nitrogen range (0.07-0.10\%) was scattered in the entire tehsil Ziarat with $0.05-0.07 \% \mathrm{~N}$ distributed in its center region along with small area in the extreme north and south while the maximum area of Sanjavi tehsil indicated total nitrogen contents in the range of $0.05-0.07 \%$ which was spatially distributed but low total nitrogen contents $(0.03-0.05 \%)$ were concentrated in the Eastern region of Sanjavi tehsil (Figure 2c). The spatial distribution of $\mathrm{P}$ as depicted in Table 3 and Figure $3 \mathrm{~d}$ revealed that $72 \%$ apple orchards' soil were low in $\mathrm{P}$ contents $\left(<4.0 \mathrm{mg} \mathrm{kg}^{-1}\right)$. Medium level $\mathrm{P}\left(3.01-5.17 \mathrm{mg} \mathrm{kg}^{-1}\right)$ is concentrated in a longitudinal wide strip at the Eastern region of both tehsils along with narrowed strip extending from north to South Eastern. While, rest of the region showed spatial distribution of $\mathrm{P}$ in low ranges (Figure 2d). Just like $\mathrm{P}$, K was also low in the entire apple growing region in district Ziarat where $50 \%$ apple orchards' soil were in low range. The semivariogram map of spatial distribution of $\mathrm{K}$ indicated that soil medium level $\mathrm{K}\left(87.20-109.15 \mathrm{mg} \mathrm{kg}^{-1}\right)$ was concentration in the western region only while rest of area depicted $\mathrm{K}$ distribution in low ranges (Figure $2 \mathrm{e}$ ).

The Variogram analysis showed that AB-DTPA extractable soil micronutrients included $\mathrm{Cu}, \mathrm{Fe}, \mathrm{Mn}$ and $\mathrm{Zn}$ were better characterized by semivariogram with stable model that expressed distance of spatial dependence of $0.08,0.09,0.16$ and $0.12 \mathrm{~km}$ for $\mathrm{Cu}, \mathrm{Fe}, \mathrm{Mn}$ and $\mathrm{Zn}$ (Table 3). The nugget:sill ratio of $85.36 \%$ for $\mathrm{Cu}$ demonstrating weak spatial autocorrelation, $8.84,61.17$ and $42.41 \%$ for $\mathrm{Fe}, \mathrm{Mn}$ and $\mathrm{Zn}$ exhibiting strong spatial autocorrelation. Other researchers also reported similar results ${ }^{(54,55)}$. The prediction of these nutrients from unsampled area is correct because ASE and RMSE have related closeness. Similar results were also reported by other researchers ${ }^{(20)}$. While, the map generated from semivariogram showing the spatial distribution of these nutrients is depicted in Figure $2 \mathrm{f}-\mathrm{i}$. The medium level soil $\mathrm{Cu}(0.38-0.49 \%)$ was distributed in the middle area of tehsil Sanjavi extending as irregular wide strip from North to South Eastern but rest of district area exhibited Cu in adequate ranges with varying concentration (Figure $2 \mathrm{f}$ ). The spatial distribution of Fe as depicted in Table 3 and Figure $2 \mathrm{~g}$ revealed that $74 \%$ apple orchards' soil were low in Fe contents $\left(<2.0 \mathrm{mg} \mathrm{kg}{ }^{-1}\right)$. Medium level Fe $\left(1.26-2.53 \mathrm{mg} \mathrm{kg}^{-1}\right)$ is concentrated on the middle region of tehsil Ziarat with small scale distribution of Fe in adequate range while rest of region of district showing poor distribution of $\mathrm{Fe}$ (Figure $2 \mathrm{~g}$ ). The spatial distribution map of soil Mn revealed adequate level $\left(>1.8 \mathrm{mg} \mathrm{kg}^{-1}\right)$ with varying degree in the whole region except with very small area, not highlight, representing Mn distribution in medium range (Figure 2h). Just like Mn, the spatial distribution map of Zn manifested that $\mathrm{Zn}$ was also adequate in the whole apple growing region with varying degree (Figure 2i). Weak to strong spatial dependence of studied chemical properties can be ascribed to intrinsic factor including soil forming factors i.e., parent material plays a key role in maintaining the spatial variability ${ }^{(56)}$. For site specific nutrient management, researchers have effectively applied the geostatistical tools to characterize the spatial variability of the region for determining the low, medium and high level of plant available nutrients ${ }^{(57)}$. The precise prediction in spatial variability and to assess the accuracy of situation, various models are tested which are based on ME, MSE, ASE, RMSE and RMSSE ${ }^{(58)}$. During the analysis, when the values of ASE (average standardized error) and RMSE (root mean square error) are closer to each other means that the prediction is accurate ${ }^{(58)}$.

\section{Conclusion}

The statistical analysis revealed that soils of apple orchards were mostly silty loam, non-saline and alkaline. Soil organic matter content was in medium to high in majority of the orchards along with adequate level of TN, $\mathrm{Cu}, \mathrm{Mn}$ and $\mathrm{Zn}$ but $\mathrm{P}, \mathrm{K}$ and Fe were in low ranges because the growers who apply manures don't use chemical fertilizer except nitrogen fertilizer indicating imbalance fertilization. The spatial structure of all physico-chemical properties, plant available macro and micronutrient was explained by a stable model. Soil $\mathrm{pH}, \mathrm{Cu}$ and $\mathrm{Mn}$ had a weak spatial dependence while, soil OM, TN, Mn and Zn had a medium spatial dependence. But soil P, K and Fe had a higher spatial dependence. This study demonstrated that the variability of soil chemical properties was associated to the management practices (fertilizer, irrigation, and other tillage practices) and local conditions (topography, climate etc.). The main limitation observed in this study was insufficient sampling from a single tree and a greater number of trees in each orchard need to be included in sampling for making representative composite sample. The data regarding use of fertilizers and composts in the apple orchards are required to confirm the actual status of nutrients during spatial variability study. Furthermore, the replenishment of nutrients particularly $\mathrm{P}, \mathrm{K}$ and Fe is necessary in the study area. The findings of this study can help in better understanding of soil properties of apple orchards in district Ziarat and site-specific fertilizer recommendation can be made for sustainable apple production with minimum losses and greater output. 


\section{References}

1) FAO (Food and Agriculture Organization). FAO Statistical Databases. 2019. Available from: http://www.fao.org.

2) GoP (Government of Pakistan). Agricultural Statistics of Pakistan, Ministry of National Food Security and Research Islamabad. 2019. Available from: https://www.pbs.gov.pk/agri-stat-tables.

3) ul Haq I, Muhammad B, Iqbal F. Effect of gypsum and farmyard manure on soil properties and wheat crop irrigated with brackish water . 2007. Available from: https://agris.fao.org/agris-search/search.do?recordID=PK2008001172.

4) Ahmad N, Saleem MT, Rashid M, Jalil A, National Fertilizer Development Center Planning and Development Division, Islamabad. Sulfur status and crop response in Pakistan soils. 1994.

5) Bogunovic I, Pereira P, Brevik EC. Spatial distribution of soil chemical properties in an organic farm in Croatia. Science of The Total Environment. 2017;584-585:535-545. Available from: https://dx.doi.org/10.1016/j.scitotenv.2017.01.062.

6) Rosemary F, Vitharana UWA, Indraratne SP, Weerasooriya R, Mishra U. Exploring the spatial variability of soil properties in an Alfisol soil catena. CATENA. 2017;150:53-61. Available from: https://dx.doi.org/10.1016/j.catena.2016.10.017.

7) Iqbal J, Thomasson JA, Jenkins JN, Owens PR, Whisler FD. Spatial Variability Analysis of Soil Physical Properties of Alluvial Soils. Soil Science Society of America Journal. 2005;69(4):1338-1350. Available from: https://dx.doi.org/10.2136/sssaj2004.0154.

8) Özgöz E. Long Term Conventional Tillage Effect on Spatial Variability of Some Soil Physical Properties. Journal of Sustainable Agriculture. 2009;33(2):142160. Available from: https://dx.doi.org/10.1080/10440040802395056.

9) Wang ZM, Song KS, Zhang B, Liu DW, Li XY, Ren CY, et al. Spatial variability and affecting factors of soil nutrients in croplands of Northeast China: A case study in Dehui county. Plant Soil Environ. 2009;55(3):110-130.

10) Kvaerno SH, Haugen LE, Borresen T. Variability in topsoil texture and carbon content within soil map units and its implications in predicting soil water content for optimum workability. Soil Till Res. 2007;95:332-379. Available from: 10.1016/j.still.2007.02.001.

11) Liu X, Zhang W, Zhang M, Ficklin DL, Wang F. Spatio-temporal variations of soil nutrients influenced by an altered land tenure system in China. Geoderma. 2009;152(1-2):23-34. Available from: https://dx.doi.org/10.1016/j.geoderma.2009.05.022.

12) Umali BP, Oliver DP, Forrester S, Chittleborough DJ, Hutson JL, Kookana RS, et al. The effect of terrain and management on the spatial variability of soil properties in an apple orchard. CATENA. 2012;93:38-48. Available from: https://dx.doi.org/10.1016/j.catena.2012.01.010.

13) Wang XH, Wang BT, Xu XY, Liu T, Duan YJ, Zhao Y. Spatial and temporal variations in surface soil moisture and vegetation cover in the Loess Plateau from. Ecol Ind. 2000;95:320-330. Available from: https://doi.org/10.1016/j.ecolind.2018.07.058.

14) Lian G, Guo XD, Fu BJ, Hu CX. Spatial variability and prediction of soil nutrients on a conty scale on the Loess Plateau-A case study of Hengshan County, Shaanxi Province. Acta Pedol Sin. 2008;45:577-584.

15) Bogunovic I, Trevisani S, Seput M, Juzbasic D, Durdevic B. Short-range and regional spatial variability of soil chemical properties in an agro-ecosystem in eastern Croatia. CATENA. 2017;154:50-62. Available from: https://dx.doi.org/10.1016/j.catena.2017.02.018.

16) Bangroo SA, Najar GR, Achin E, Truong PN. Application of predictor variables in spatial quantification of soil organic carbon and total nitrogen using regression kriging in the North Kashmir forest Himalayas. CATENA. 2020;193. Available from: https://dx.doi.org/10.1016/j.catena.2020.104632.

17) Naveed M, Herath L, Moldrup P, Arthur E, Nicolaisen M, Norgaard T, et al. Spatial variability of microbial richness and diversity and relationships with soil organic carbon, texture and structure across an agricultural field. Applied Soil Ecology. 2016;103:44-55. Available from: https://dx.doi.org/10.1016/j. apsoil.2016.03.004.

18) Deakin G, Tilston EL, Bennett J, Passey T, Harrison N, Fernández-Fernández F, et al. Spatial structuring of soil microbial communities in commercial apple orchards. Applied Soil Ecology. 2018;130:1-12. Available from: https://dx.doi.org/10.1016/j.apsoil.2018.05.015.

19) Hou L, Liu Z, Zhao J, Ma P, Xu X. Comprehensive assessment of fertilization, spatial variability of soil chemical properties, and relationships among nutrients, apple yield and orchard age: A case study in Luochuan County, China. Ecological Indicators. 2021;122(107285). Available from: https: //doi.org/10.1016/j.ecolind.2020.107285.

20) Yang F, Wei X, Huang M, Li C, Zhao X, Zhang Z. Spatiotemporal variability of soil organic carbon for different topographic and land use types in a gully watershed on the Chinese Loess Plateau. Soil Research. 2016;59(4):383-395. Available from: https://doi.org/10.1071/SR19317.

21) Zhang D, Zheng LW, Han MY, Gao CX, Luo WW, Ma JJ. Studies of the standard range of the soil nutrients in apple orchard in Loess Plateau. Acta Hortic Sin. 2016;43:121-131. Available from: 10.16420/j.issn.0513-353x.2015-0347.

22) Sharma R, Sood K. Characterization of Spatial Variability of Soil Parameters in Apple Orchards of Himalayan Region Using Geostatistical Analysis. Commun Soil Sci Plant Anal;2020(8):1065-1077.

23) Rehman Z, Hyderb SI, Arshadullah M, Muhammad S. Nitrogen status of soil and plants in apple orchards of Quetta valley, Pakistan. Pak J Sci Ind Res. 2015;58(1):54-55.

24) Melherb DV. Soil fertility. 5th ed. University Press. 1963.

25) Mujtaba G, Raisani AR, Kakar H, Nissa T, Shehzad I, E A. Assessment of soil physicochemical properties and macronutrient status of fruit bearing apple orchards in three districts of Balochistan. Int J Life Sci. 2015;9(1-4):3247-3256.

26) Hidayatullah, Panezai GM, Kethran R, Agha S, Alizai NA, Khan Z. Zinc of apple orchards across apple growing regions of Balochistan. Pure Appl Biol. 2019;8(1):920-930. Available from: http://dx.doi.org/10.19045/bspab.2019.80034.

27) Uygur V, Rimmer DL. Reactions of zinc with iron-oxide coated calcite surfaces at alkaline pH. European Journal of Soil Science. 2000;51(3):511-516. Available from: https://dx.doi.org/10.1046/j.1365-2389.2000.00318.x.

28) Yang Y, Zhang S. Computing Technologies in Agriculture. In: Li D, Zhao C, editors. Computer and Computing Technologies in Agriculture II, Volume 1;vol. 258. Springer. 2008;p. 565-571. Available from: https://www.springer.com/gp/book/9781441902085.

29) Gaston LA. Spatial Variability of soil properties and weed population in the Mississippi delta. Soil Sci Soc Am J. 2001;65:470-479. Available from: https://doi.org/10.2136/sssaj2001.652449x.

30) Goovaerts P. Geostatistics in soil science: state-of-the-art and perspectives. Geoderma. 1999;89(1-2):1-45. Available from: https://dx.doi.org/10.1016/ s0016-7061(98)00078-0.

31) Lopez-Granados F, Jurado-Exposito M, Atenciano S, Garcia-Ferrer A, Orden MSDL. Spatial variability of agricultural soil parameters in southern Spain. Plant Soil. 2002;246:97-105. Available from: https://ink.springer.com/article/10.1023/A:1021568415380.

32) Bouyoucos GJ. Hydrometer Method Improved for Making Particle Size Analyses of Soils. Agronomy Journal. 1962;54(5):464-465. Available from: https://dx.doi.org/10.2134/agronj1962.00021962005400050028x. 
33) Estefan G, Sommer R, Ryan J, International Center for Agriculture Research in the Dry Areas (ICARDA). Methods of Soil, Plant and Water Analysis: Laboratory Manual. 3rd ed.. 2013.

34) Walkley A, Black IA. An examination of the Degtjareff method for determining soil organic matter and a proposed modification of the chromic acid titration method. Soil Science. 1934;37(1):29-38. Available from: https://dx.doi.org/10.1097/00010694-193401000-00003.

35) Mclean EO. Soil pH and lime requirement. In: Page AL, editor. Methods of soil analysis, Part 2: chemical and microbiological properties. $1982 ; \mathrm{p} .199-224$. Available from: https://doi.org/10.2134/agronmonogr9.2.2ed.c12.

36) Soltanpour PN, Schwab AP. A new soil test for simultaneous extraction of macro- and micro-nutrients in alkaline soils. Communications in Soil Science and Plant Analysis. 1977;8(3):195-207. Available from: https://dx.doi.org/10.1080/00103627709366714.

37) Olsen SR, Cole CV, Watanabe FS, Dean LA. . Estimation of available phosphorus in soils by extraction with NaHCO3, USDA Cir.939. 1954. Available from: https://www.scirp.org/(S(351jmbntvnsjtlaadkposzje) $) /$ reference/ReferencesPapers.aspx?ReferenceID=1061087.

38) Jones JB. Kjeldahl method for nitrogen determination. Athens, GA, USA. Micro-Macro Publishing Inc. 1991. Available from: https://byjus.com/chemistry/ kjeldahl-method/.

39) Samra JS, Singh VP, Sharma KNS. Analysis of spatial variability in sodic soils 2. Point and block - kriging. Soil Sci. 1988;145(4):250-256.

40) Aggelopoulou KD, Pateras D, Fountas S, Gemtos TA, Nanos GD. Soil spatial variability and site-specific fertilization maps in an apple orchard. Precision Agriculture. 2011;12:118-129. Available from: https://dx.doi.org/10.1007/s11119-010-9161-x.

41) Saleem M, Saddudin, Bhatti SM, Gandahi AW, Rajpar I. Status of soil macronutrients in apple orchards of district Killa Saifullah Balochistan. PakJ Agri Agril Engg Vet Sci. 2018;34(1):22-30.

42) Hussain A, Ali H, Begum F, Hussain A, Khan M, Guan Y, et al. Mapping of Soil Properties under Different LandUses in Lesser Karakoram Range, Pakistan. Polish Journal of Environmental Studies. 2021;30:1181-1189. Available from: https://dx.doi.org/10.15244/pjoes/122443.

43) Lehman J, Kleber M. The continuous nature of soil organic matter. Nature. 2015;528:60-68. Available from: 10.1038/nature16069.

44) Moura E, Gehring C, Braun H, Junior AF, Reis F, Aguiar A. Improving Farming Practices for Sustainable Soil Use in the Humid Tropics and Rainforest Ecosystem Health. Sustainability. 2016;8:841. Available from: https://dx.doi.org/10.3390/su8090841.

45) Reijonen I, Metzler M, Hartikainen H. Impact of soil $\mathrm{pH}$ and organic matter on the chemical bioavailability of vanadium species: The underlying basis for risk assessment. Environmental Pollution. 2016;210:371-379. Available from: https://dx.doi.org/10.1016/j.envpol.2015.12.046.

46) ul Haq Z, Ullah Z, Ahmed S, Siddiqui MR, Saduddin. Nutritional status of apple orchards soils in district Qilla Saifullah (Balochistan). Pure and Applied Biology. 2018;7(2):797-809. Available from: https://dx.doi.org/10.19045/bspab.2018.70099.

47) Khalid R, Mahmood T, Bibi R, Siddique MT, Alvi S, Naz SY. Distribution and indexation of plant available nutrients of rainfed calcareous soil of Pakistan. Soil Environ. 2012;31(2):146-151.

48) Sallato B, Dupont T, Granatstein D. Tree Fruit Soil Fertility and Plant Nutrition in Cropping Orchards in Central Washington. In: WSU Tree Fruit. 2018. Available from: http://treefruit.wsu.edu/orchard-management/soils-nutrition/fruit-tree-nutrition/.

49) Hou L, Liu Z, Zhao J, Ma P, Xu X. Comprehensive assessment of fertilization, spatial variability of soil chemical properties, and relationships among nutrients, apple yield and orchard age: A case study in Luochuan County, China. Ecological Indicators. 2021;122. Available from: https://dx.doi.org/10. 1016/j.ecolind.2020.107285.

50) Begum F, Abbas H, Ali S, Ali D, Mumtaz S, Khan MZ. Soil quality and organic carbon stock across the different land use in a mountainous landscape of Karakoram region. Fresenius Environ Bull;2020(01):503-503. Available from: https://doi.org/10.15244/pjoes/122443.

51) Ahmed H, Siddique MT, Ali S, Abbasi NA, Khalid A, Khalid R. Micronutrient indexing in the apple orchards of Northern Punjab, Pakistan using geostatistics and GIS as diagnostic tools. Soil Environ. 2014;33(1):7-16. Available from: www.se.org.pk.

52) Hillel D. Soil physical attributes. Soil In The Environ. 2008;p. 55-77. Available from: 10.1016/b978-0-12-348536-6.50010-1.

53) Vasu D, Singh SK, Sahu N, Tiwary P, Chandran P, Duraisami VP, et al. Assessment of spatial variability of soil properties using geospatial techniques for farm level nutrient management. Soil and Tillage Research. 2017;169:25-34. Available from: https://doi.org/10.1016/j.still.2017.01.006.

54) Fan FJ, Song TQ, Huang GQ, Zeng FP, Peng WX, Du H, et al. Characteristics of spatial variation of soil nutrients in sloping field in a gorge karst region, southwest China. Ying Yong Sheng Tai Xue Bao;25(1):92-98.

55) HongJu Z, ShanShan M, KeLi Z, ZhengQian Y, ZhiYong W, Shan B. Soil fertility and its spatial distribution for Corya cathayensis stands in Lin’an, Zhejiang Province. Journal of Zhejiang A\&F University . 2018;35(4):664-673. Available from: https://www.cabdirect.org/cabdirect/abstract/20183327486.

56) Cambardella CA, Moorman TB, Novak JM, Parkin TB, Karlen DL, Turco RF, et al. Field-Scale Variability of Soil Properties in Central Iowa Soils. Soil Science Society of American Journal. 1994;58(5):1501-1511. Available from: https://doi.org/10.2136/sssaj1994.03615995005800050033x.

57) Eltaib SM, Soom M, Hanafi MM, Shariff A, Wayayok A. Spatial variability of N, P, and K in rice field in Sawah Sempadan. Malaysia Songklanakarin J Sci Technol. 2002;24:321-328. Available from: https://rdo.psu.ac.th/sjstweb/journal/24-2/15.pdf.

58) Robinson TP, Metternicht G. Testing the performance of spatial interpolation techniques for mapping soil properties. Computers and Electronics in Agriculture. 2006;50(2):97-108. Available from: https://dx.doi.org/10.1016/j.compag.2005.07.003. 